\title{
Essays in Refusal: Pre-Theoretical \\ Commitments in Postmodern Anthropology and Critical Race Theory
}

\author{
Derek P. Jinks
}

The necessity of reform mustn't be allowed to become a form of blackmail serving to limit. reduce or halt the exercise of cntucism. Under no circumstances should one pay attention to those who tell one: "Don't criticize, since you're not capable of carrying out a reform." That's ministerial cabinet talk. Critlque doesn't have to be the premise of a deduction which concludes: this then is what needs to be done. It should be an instrument for those who fight, those who resist and refuse what is. Its use should be in processes of conflict and confrontation, essays in refusal.

- Michel Foucault

\section{INTRODUCTION: THE SOCIOLOGY OF CRITIQIE}

Michel Foucault's compelling and poetıc methodological manifesto describes the nature of "critique" and, thereby, the proper role of the critic. For Foucault, "critique" was more than a means 10 an end: criticism was itself an act of resistance and refusal." Toward this end, Foucault sought to decouple

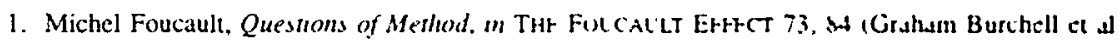
eds., 1991).

2. This characterization of Foucault is postuon is contronerstal Compare Johis $S$ Revisus.

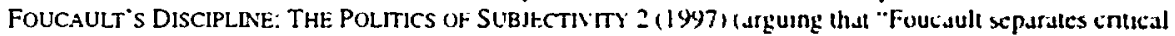
thought from postuve visions of soctal worlds that wall replace lodus s redity"). and at at 3 (contending that, for Foucault. "Ic]riticism needs to stop being thought of ds purely a mesns and instedd should iake

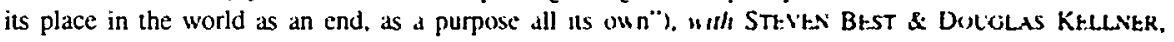
POSTMODERN THEORY. CRITICAL INTERROGATIONS 58.59 (199I) (stalung that Fouldult's approsth is "intended to facilitate the development of new forms of subjectuly and values" 1 , and ad at 59 , Whale Foucault never provided any conception of human agency. he did gesture loudrds \& posituve reconstruction of subjectuvily in a posthumanist problemalie") Foucult's seemingly cuntradicton statements encourage alternate interpretatons Sec, eg. Aioum (homsh) \& Michel Foucdult. Hurun

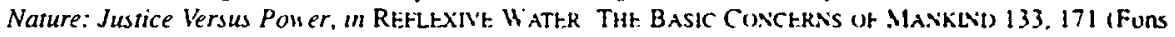

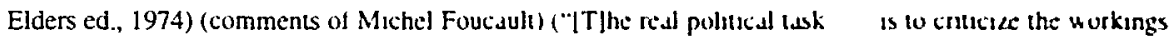
of institutions . . to criticize and atlack them in such a manner that the polltical welene which hes aluays exercised itself obscurely through them will be unmasked. so that une can fight sganst them ",

This Note does not attempt to defend either interpretation of Foucaull's worh Rather. Its anslysis of postmodemism utilizes one interpretation of Foucault-that criticasm should not be tucd to any polttical 
criticism from positive programs for social and political change. ${ }^{3}$ Criticism is, according to this view, a negative operation-"essays in refusal"-resisting and rejecting "what is" without regard for "what needs to be done." For this reason, Foucault's views have occasionally been labeled "rejectionist." Such "rejectionist" claims, in turn, exemplify the most feared aspects of a new challenge to traditional legal thought: postmodernism. ${ }^{6}$

program-as a placeholder for a prominent understanding of critical practice. That is, Foucault is often associated with this understanding of critique; and, as such, his work serves a useful heuristic function. Clearly, Foucault's work provides important conceptual resources for the scholar-activist. See infra Section IV.B (utilizing Foucauldian conceptions of power and discourse).

3. See RANSOM, supra note 2, at 3 (arguing that Foucault stresses the values of criticism "independent of dubious projects for fundamental social change").

4. Many commentators have rejected this line of Foucault's thought. See, e.g., JORGEN HABERMAS, THE PHiLOSOPHICAL DiscouRSE OF MODERNITY 238-93 (Frederick G. Lawrence trans., MIT Press 1987) (1985) (describing Foucault's views as necessarily involving "performative contradiction"); Nicos Poulantzas, STATE, Power, Socialism 146-53 (Patrick Camilier trans., New Left Books 1978) (1978) (rejecting Foucault's view of power); Charles Taylor, Foucault on Freedom and Truth, in FoucAuLT: A CrITICAL Reader 69 (David Couzens Hoy ed., 1986).

Many progressive legal scholars also denounce this understanding of critical practice. See, e.g., Guyora Binder, What's Left?, 69 TEx. L. REv. 1985, 1985-86 (1991) (“Radical theory's recent preoccupation with critical technique represents a strategic retreat from political engagement. . . . Straddling the widening gap between 'radical' and 'chic,' critical theorists are increasingly tempted to turn the cutting edge of critique against radicalism itself."); Bernard Yack, Toward a Free Markesplace of Social Institutions: Roberto Unger's "Super-Liberal" Theory of Emancipation, 101 HARV. L. REV. 1961, 1961-62 (1988) (book review) ("[W]e now find radical theorists taking the lead in attacking totalistic theories of human emancipation. . . . But why we must do so and for what alternative are questions that . . they seem reluctant to discuss.... [Instead their] current obsession... [is] deconstructing all positive theoretical claims." (footnotes omitted)).

5. Nancy Fraser, UnRuly Practices: Power, Discourse, and Gender in Contemporary SOCIAL THEORY 36 (1989); see also id. at 35-50, 52 (describing multiple ways in which Foucault is characterized as "rejectionist" and concluding that Foucault should be understood as a "strategic rejectionist").

6. Characterizing postmodernism as a "new" development in the legal academy might at first blush seem inappropriate. "Postmodem" legal theorizing arguably dates to the early writings of the Critical Legal Studies movement. See, e.g., ROBERTO MANGABEIRA UNGER, LAW AND MOdERN SOCIETY: TOWARD a CRITICISM OF SOCIAL THEORY (1976); Duncan Kennedy, Form and Substance in Private Law Adjudication, 89 HARV. L. REv. 1685 (1976) [hereinafter Kennedy, Form and Substance]; Duncan Kennedy, The Structure of Blackstone's Commentaries, 28 BuFF. L. REV. 205 (1979) (hereinafter Kennedy, Blackstone). I describe postmodernism as a "new" development to emphasize that the full implications of postmodern legal theorizing are not yet discernible. Postmodern legal theory has not settled into an identifiable niche in the legal academy. Professor Jack Balkin provides the most compelling sustained account of postmodern legal theory. See J.M. Balkin, Deconstructive Practice and Legal Theory, 96 YALE L.J. 743 (1987); J.M. Balkin, Transcendental Deconstruction, Transcendent Justice, 92 MICH. L. REv. 1131 (1994) [hereinafter Balkin, Transcendental Deconstruction].

"Postmodernism" is a slippery and deeply contested term. See FREDERIC JAMESON, POSTMODERNISM, OR, THE CUlTuRal LOGIC OF LATE CAPTTALISM at xxii (1991) (stating that "the concept lof postmodernism] is not merely contested, it is also internally conflicted and contradictory"). Indecd, any attempt to define postmodernism "must disavow postmodernism: a definition would reduce postmodernism to some fundamental core or essence, which would be too foundationalist, too essentialist, too modernist." Stephen M. Feldman, Diagnosing Power: Postmodernism in Legal Scholarship and Judicial Practice (with an Emphasis on the Teague Rule Against New Rules in Habeas Corpus Cases), 88 Nw. U. L. REv. 1046, 1047 (1994). For an excellent survey of the term's use in legal literature, see J.M. Balkin, What $l s$ a Postmodern Constitutionalism?, 90 MiCH. L. REV. 1966 (1992).

Given the nature of this Note's argument, an analytically rigorous definition of postmodernism is not necessary. I use the concept "postmodernism" to refer to theoretical projects that celcbrate subjectivity and radical skepticism. For the purposes of this Note, postmodernism denotes many related-even if distinct-critical discourses that share this commitment to radical skepticism. Canonical definitions of 
In this Note, I challenge Foucauldian "rejectionism" by suggesung, through an example, that criticism cannot and should not assume an imeducibly oppositional stance. Critique is indeed "a challenge directed to what $1 \mathrm{~s}^{\text {": }}$ " this challenge, however, should not be reduced to an "insurrectionary gesture." I forward two broad claims. First, criticism itself should be understood as a social practice. Such an understanding demonstrates that certain characterizations of postmodernism as an antifoundational, nihilistic retreat from struggles for justice have no referent in the social world. Second, this sociological understanding of criticism provides scholars with useful conceptual resources with which to guide the productive incorporation of postmodern insights into legal scholarship.

Debates about the propriety of postmodernism's antifoundational thinking have rapidly assumed a central role in many areas of legal inquiry. ${ }^{10}$ Many legal scholars lament the arguably paralyzing, solipsistic mood of postmodernism," while others celebrate postmodernism's putative emancipatory commitment to multiplicity, subjectivity, and indeterminacy."2 Without engaging these debates directly, this Note analyzes the impact of the "postmodern turn" on the Critical Race Theory (CRT) movement."

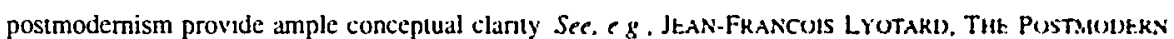
CONDITION: A REPORT ON KNOWLEIXGE at XXIN (Geoll Bennington \& Bran Massunu trans, Lniversity of Minn. Press 1984) (1979) (defining postmodernism is "increduluty tuward metunarratues") One detıning charactenstic of postmodemism is anutoundationalism Ser CRAiG CALHOUN. CRTICAL. SIXIAL ThitokY 100 (1995) (listing antifoundationalısm as one of four fundamental strands of pustmodemusmi). Enc Blumenson, Mapping the Limis of Skepticism in Las and Morals. 7.4 TtX L RtY 523. 527 n 9 (1496) (describing one central teature of postmodem legal theory as antifoundationalism. Jetined as "the ided that

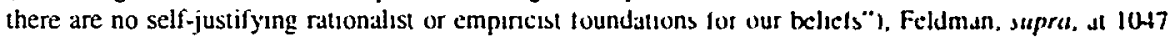
("Postmodernism rejects the very possibility of essences. cores, or loundations that undergirds modernis[m].").

For sound and accessible introductions to postmodern thought, see BtST \& KHLLNtK, supra nute?. STEVEN CONNOR, POSTMODERNIST CULTURE. AN INTRODUCTION TO THHORIFS of THI CONTFMPUKAKY

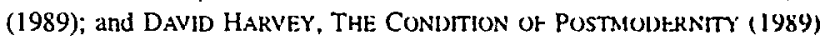

7. Foucault, supra note 1 , at 84

8. Shelden S. Wolin, On the Theon and Pracuce of Power, in AFtrk Fulcallt HeMasistic KNOWLedge, Postmodern Challenges 179. 179 (Jonathan Arat ed, 1991)

9. For a similar line of argument, see ALEX Callinicos, Against Pustmiotirknism a Makxist CRITIQue 9-12 (1989).

10. The growing influence of postmodemism in the legal academy is doxumented in GakY MiNi)A. POSTMODERN LEGAL MOVEMENTS. LAW ANI JURISPRUI)ENCF AT (FNTUKY'S ENi) (1945),

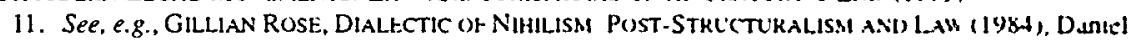

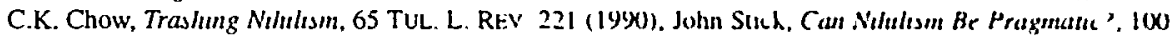
HARV. L. REV. 332 (1986).

12. Many scholars embrace radical skepucasm, makıng deconstrucuse clams a central or a major pan

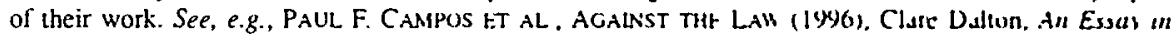
the Deconstruction of Contract Doctrme, 94 YaLt L J 997 (1985). N1.th G Kelman. Trashung. 36 STiv L. REV. 293 (1984); Kennedy, Form and Substauce. supra nole 6, Kennedy. Blackstonte, supra note 6. Piene Schlag, Nonnatue and Nowhere To Go. 43 STAN L RH 167 (19x), Patue Schldg. Normathan) and the Polntics of Form, 139 U. PA. L REV 801 (1991), Juseph Willism Singes. The Plaver and the Cards: Nihilism and Legal Theon: 94 YALt LJ I (1984)

13. The CRT literature is vast and varied Two introductory seaders proside ample esidence ot the

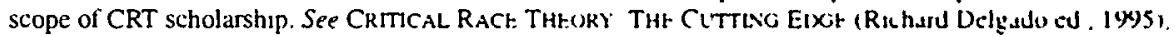

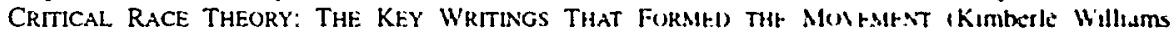
Crenshaw et al. eds., 1995) For an annotated biblography ol umportant works, soc Richard Delgadu \& Jean 
CRT is often characterized-usually as a precursor to criticism-as postmodern. ${ }^{14}$ In fact, CRT seemingly strikes an ambivalent pose on the postmodern question; ${ }^{15}$ some CRT scholars applaud the incorporation of postmodernism into "outsider jurisprudence," 16 while others warn of the dangers of narcissism ${ }^{17}$ and political paralysis. ${ }^{18}$ This surface ambivalence, however, masks a deeper consensus: While CRT scholars reach different conclusions on the usefulness of postmodernism, they apply the same pre-

Stefancic, Critical Race Theory: An Annotated Bibliography, 79 VA. L. REv. 461 (1993). For an informative history of the movement, see Richard Delgado, Legal Scholarship: Insiders, Outsiders, Editors, 63 U. Colo. L. REv. 717, 721 n.34 (1992). A prominent feature of the intellectual, institutional, and political development of CRT relevant to this Note is that the movement began in many respects as a reaction against the deconstructive excesses of Critical Legal Studies. See Symposium, Minority Critique of the Critical Legal Studies Movement, 22 HARV. C.R.-C.L. L. REv. 297 (1987).

14. See, e.g., MNDA, supra note 10, at 167-85 (categorizing CRT as a "postmodern legal movement"); see also Chow, supra note 11, at 223 n.1 (defining "nihilist" jurisprudence as embodying the "current positions of some legal academics that law and illegitimate power are inseparable, that all law is power, and that our current legal system allows those empowered to dominate and oppress other groups"); Douglas E. Litowitz, Some Critical Thoughts on Critical Race Theory, 72 NOTRE DAME L. REv. 503, 516 (1997) (attacking CRT for failing to "find a replacement approach [to liberalism] and understand how this new approach will preserve individual rights"); Thomas Morawetz, Understanding Disagreement, the Root lssue of Jurisprudence: Applying Wittgenstein to Positivism, Critical Theory, and Judging, 141 U. PA. L. REV. 371, 434-36, 438 (1992) (describing the "conceptual relativity" and "antifoundational" underpinnings of CRT); Jeffrey Rosen, The Bloods and the Crits: O.J. Simpson, Critical Race Theory, the Law, and the Triumph of Color in America, NEw REPUBL.JC, Dec. 9, 1996, at 27, 29 (describing CRT as a "poststructuralist" retreat from problems that minorities face). Some proponents of CRT contribute to this (mis)understanding of the movement. See, e.g., Feldman, supra note 6, at 1102-03 ("Postmodernism, in short, generates different voice scholarship by encouraging outgroup members to uncover previously suppressed truths and meanings. Different voice scholars, from this perspective, exemplify postmodernism; they are prototypical postmodemists."); Gary Peller, The Discourse of Constitutional Degradation, 81 GEo. L.J. 313, 330-36 (1992) (attributing to CRT a commitment to strong social constructionism as the "main epistemological point []" of the movement).

15. See Veronica Gentilli, Comment, A Double Challenge for Critical Race Scholars: The Moral Context, 65 S. CAL. L. REv. 2361, 2362 (1992) (describing the "double challenge" confronting critical race scholars, namely that "[o]n the one hand, they must dispel the myth of objectivity that underlics our current understanding of the law and its moral foundation, while on the other, they must prove that it is possible to obtain a true and objective conception of justice").

16. See, e.g., Robert S. Chang, Toward an Asian American Legal Scholarship: Critical Race Theory; Post-Structuralism, and Narrative Space, 81 CAL. L. Rev. 1243, 1286 (1993) (arguing that the poststructuralist critique reveals that "political action is all that will be left"); Anthony E. Cook, Reflections on Postmodernism, 26 NEw ENG. L. REV. 751, 754 (1992) ("Postmodern critique might be thought of as a strategy for bringing to the surface suppressed narratives and voices drowned out by the univocal projections of master narratives."); Charles R. Lawrence, III, The Word and the River: Pedagogy as Scholarship as Struggle, 65 S. CAL. L. REV. 2231, 2252 (1992) (arguing that those workıng to end ricism should make a strong commitment to a subjective perspective); cf. Mark Tushnet, An Essay on Rights, 62 TEX. L. REV. 1363, 1402 (1985) (claiming that it is "tremendously liberating" to recognize "that nothing is necessary, that everything is contingent, [and] that I need not resign myself to how things are").

The phrase "outsider jurisprudence" was coined by Mari Matsuda. See Mari J. Matsuda, Public Response to Racist Speech: Considering the Victim's Story, 87 Mich. L. REv. 2320, 2323 n.15 (1989)

17. See Litowitz, supra note 14, at 516-20 (describing the "danger[s] of narcissism").

18. See, e.g., Deborah L. Rhode, Feminist Critical Theories, 42 STAN. L. REV. 617, 619-20 (1990) (arguing that postmodernism creates political and theoretical difficultıes for outsider jurisprudence); Robin L. West, Adjudication Is Not Interpretation: Some Reservations About the Law-as-Literature Movement, 54 TENN. L. REV. 203, 246-53 (1987) (branding subjective interpretivists as "conservative"); Jennifer Wicke, Postmodern Identity and the Legal Subject, 62 U. CoLo. L. REv. 455, 455 (1991) (arguing that "the costs of a shotgun marriage between [postmodernism and the law] are too high"). 
theoretical criteria ${ }^{19}$ in the course of generating their respectuve conclusions. That is, CRT does not (and should not) embrace Foucault's understanding of the critic as "rejectionist."20 This Note elaborates on this point by offering an examination of the ways in which another discipline-anthropologyselectively appropriates insights from postmodemism. Such an exercise demonstrates that the practice of CRT, properly understood, is not an antifoundational enterprise.

Although my understanding of the law's conceptual and normative commitments is shaped in no small measure by the insights of CRT, this Note is properly understood as a commentary on CRT rather than an instance of CRT. Additionally, I offer no criticism of CRT; nor do I suggest abandoning existing CRT research programs. Rather, this Note provides a sociological perspective ${ }^{21}$ on the practice of $\mathrm{CRT}^{22}$ as a way of deciphering the socially constructed boundaries that encircle and limit the CRT project. ${ }^{3}$

More specifically, I suggest that CRT occupies a delimited domain of legal thought within which the range of acceptable propositions is a function of

19. These criteria are "pre-theoretical" in the sense that their vtability is nut itselt subjected to theoretical reflection. Compare this descroption with Steven Best and Doug Kellner's accoum of critical theory's "metatheoretical assumpuons", representation, social coherence. and sgenc) BR-ST \& KFLLStK. supra note 2, at 257. Best and Kellner do not andlya the issue in the way I propase here As d consequence, the status of these "metatheoretical assumptions" as discursive toundations for critual theory is unclear. As I discuss at length below, the pre-theoretical charatter of cenatil concepts provides unshakable foundations. See infra Pans II. III

20. My argument is thus both descriptuce and prescrupuve On a descripuse level. I clatm that CRT is a socially organized critical project wedded to certan identilisble. pragmath loundations (RT is nut. therefore, an antifoundational, posimodern legal movement In dedition. on a prestrplise lesel. I suggest ways in which postmodernism might be productuvely appropnuted to lurther the CRT projed

21. Zygmunt Bauman provides a uselul capsule summany of the sociolugtid approsth

[W] hat sets sociology apart and guves it its distuncuve charater is the habit of sewing human actsons as elements of wrder figurations that is, of a non-idndom asembly of thlurs laked together in a web of mutual dependencr (dependency being a state in which the probubility thut the action will be underaken and the chance of lis success change in relation lo what st tors ate. or do, or may do). Sociologists would ask whil consequences this being lucked tugether would have for the possible and the actual behaviour of human actors ZYGMUNT BAUMAN, THINKING SOCIOLOGICALLY 7.8 (1990)

22. See generally Angela P Harns. Foreword The Jurtsprudence of Reconstrut ton, S2 C iL L RH 741, 745 (1994) ("Intellectual movements are prackues games whose rules afe aludys evoling. played by communities with fuzzy boundanes " (footnote omitted)). Edustu L Ruban. The Pratice cuth liscourse of Legal Scholarship, $86 \mathrm{MiCH}$. L. ReV 1835. 1841 (1988) ("IA]n desdemic diselphint is not a bud of objective information, or a set of techniques for discovenng such information. but a pratke. a system of socially constituted modes of argument shared by a communt? of schulars",

23. I suggest nether that CRT is narrow in scope nor that it is static. instedu, 1 suggest that what the legal academy-and cntucal race theorists themselves-huve come wo understand as (RT is an identitiable domain of inquiry within which cerain organizang principles hold On the dynamic nature ol CRT

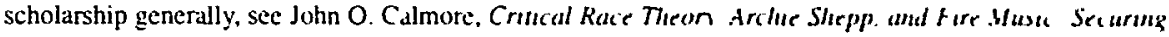
an Authentic Imellectual Life in a Mulncultural World. 65 S CAL L RF 2129. 2161 1 19921. and Richurd Delgado, Brewer's Plea: Crincal Thoughs on Common Cause. If VAxD L RF 1, 6.7 1991, Cg Patricia Williams, The Obligng Shell: An Informal Essas on Formal Equal Opportumn, s7 Mlicu L RrV 2128,2151 (1989) ("It is this perspectuve, the ambi-1 dlent, mulus dent ws! of seing that is, I thuth, at the heart of what is called critucal theory, fenunist theory, and the somalled minurity crillyut th has to do with a fiud positioning that sees back and forth deross boundaf [1es] 
identifiable pre-theoretical commitments. ${ }^{24}$ Pre-theoretical commitments are the unquestioned assumptions that make any theoretical discourse possible. ${ }^{25}$ Any distinctive style or method of analyzing problems necessarily entails certain conceptual commitments. Consider, for example, theories of gaming or strategy. Chess strategists may disagree about the most appropriate defense against an English opening, but they unambiguously agree on, among other things, the game's ultimate objective. This consensus is a condition of possibility for the range of disagreements that comprise chess theory. Simply put, chess is chess in virtue of this agreement.

These pre-theoretical commitments therefore establish pragmatic foundations for any theoretical discourse. ${ }^{26}$ The identifiable pre-theoretical commitments of CRT establish discursive limits on the range of theoretical propositions that could properly be characterized as CRT. That is, any project that involves departure or derogation from these commitments is not identifiable as CRT. My claim is not that scholars are unable to theorize or interrogate the pre-theoretical commitments of CRT. Rather, I suggest that the ability of the scholar to reflect on any issue from within a disciplinary framework is constrained by that discipline's pre-theoretical commitments. ${ }^{27}$

24. By pre-theoretical commitments, I mean a practice's conceptual commitments that structure background understandings of the theoretical project. The selection of relevant facts, appropriate methods, and usable principles of verification-all theoretical concerns-necessarily takes place against the backdrop of certain pre-theoretical understandings. See PETER L. Berger \& ThOMAs LUCKMANN, The SOCIAL CONSTRUCTION OF REALITY 12 (1966) (suggesting that the reach of sociological vision does not extend to approaches that would challenge the pre-theoretical commitments of sociology and that "[t]o include epistemological questions concerning the validity of sociological knowledge in the sociology of knowledge is somewhat like trying to push a bus in which one is riding"). Similar concepts are more fully developed in the philosophy of science. See, e.g., LUDwIK FLECK, GENESIS AND DEVELOPMENT OF A SCIENTIFIC FACT 23-27 (Fred Bradley \& Thaddeus J. Trenn trans., University of Chicago Press 1979) (1935) (describing the analogous concept of a "proto-idea").

25. Critics of this formulation might claim that no extra-theoretical perspective exists. This potential criticism helps clarify my point. Indeed, the concept of pre-theoretical commitments is itself a theoretical construction. Specific pre-theoretical commitments define the scope of particular modes of inquiry. That is, pre-theoretical commitments are not necessarily shared across disciplines. As a consequence, one mode of inquiry-sociology, for example-is capable of specifying the extra-theoretical features or preconditions of another-history, for example. Sociological theory could describe phenomena that are decidedly extratheoretical for historiography. Understood in this way, the notion of pre-theorctical commitments gives theoretical expression to extra-theoretical phenomena.

26. To clarify, my use of the term "foundations" does not refier to philosophical (or theoretical) foundations. Rather, I elaborate the notion of pre-theoretical commitments to highlight the sociological dimension in any critical practice. That is, the foundations described are social.

27. In this sense, my project draws upon and supplements Jack Balkin's work on "transcendental deconstruction." See J.M. Balkin, Being Just with Deconstruction, 3 Soc. \& LEGaL STUD. 393 (1994) [hereinafter Balkin, Being Just]; Balkin, Transcendental Deconstruction, supra note 6. Balkin notes that deconstructive techniques "appear to preclude the possibility of any stable conception of the just or the good that could provide the basis for political belief or the authority for political action." Balkin. Bemg Just, supra, at 393. Balkin, however, qualifies this view by distinguishing the rhetorical practice of deconstruction from deconstruction itself. See id. at 402. The theory of deconstruction-a technique or tool, like all theories-may not allow for the possibility of justice, but the use of deconstruction as a political strategy nevertheless demonstrates a commitment to justice. Elaborating this distinction, Balkin provides a nuanced account of the relationship between deconstruction and justice by claiming that "deconstructive arguments made by human beings are necessarily partial in their perspective and limited in their scope. As a result, deconstructive argument does not necessarily further the interests of justice but is rather a 
Three related propositions are suggested by this analysis. First, CRT-even in its most deconstructive moments-inhabits an identifiable "political location." 28 Second, this "political location" provides firm foundations that structure CRT as a theoretical (and practical) discourse. Third, the source of these foundations is social. Toward this end, I aim to demonstrate some of the ways in which CRT -as a socially organized practice-necessarily involves and informs what Michel Foucault derided as "ministerial cabinet talk." In short, the characterization of CRT as antifoundational-postmodern in the strong sense-is flawed. Furthermore, I claim that CRT's pre-theoretical commitments specify the conditions under which CRT should appropriate the insights of postmodernism. In this way, the Note strives to articulate a "sociology of critique" that would provide an account of the uses and abuses of "postmodern CRT." 30

The Note's argument proceeds as follows. Par II outlines and analyzes the debate over postmodernism in CRT. In this part, I point out some of the conceptual difficulties encountered by Critical Race Theorists in their attempts to answer Foucault's call for "essays in refusal." I suggest that the very ways in which CRT assumes an oppositional stance to traditional civil rights scholarship limit the breadth and depth of CRT's critical project. This analysis suggests that CRT qua CRT involves certain pre-theoretical commitments; namely, CRT is committed to the concept of racial justice-a concept that is in turn wedded to a range of other conceptual commitments. The reasoning in this part suggests that the question, properly specified, on the relationship between CRT and postmodernism is the following: What is the relationship

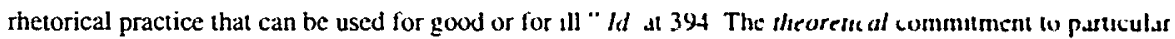
argumentative techniques-deconstructuon, for example-can be disunguished from the suurces of this commitment. For Balkin, the commitment to justice is extra-theoretucal, justice is a "yesming " Bulkin. Transcendental Deconstruction, supra note 6, at 1140 In this Nole, I dttempt to give theoretical expresston to Balkin's approach by elaboratung a "sociology of entuque" Ser infra note 30 and atiompany ing text That is, I analyze the relationshp between this "yearning" and the conceptual commiments of critusl discourses. In addition, this point also highlights that my clatums. although grounded in a discussion of anthropology and CRT, are equally applicable to any theoretical discourse

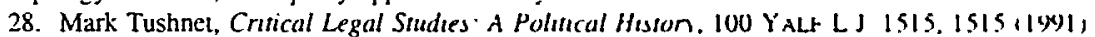

29. See supra text accompanying note I Foucault arguably considered the fule of the critte 15 fundamentally oppositional. That is, critses should not truncite or blunt the torce of cntical anslyses to accommodate the "necessity of reform" Cabinet minisiers must worn viet the pruper pultes goals and mechanisms given the realpolitk. For Foucault. crique involves the renuncistion of this instituliond. bureaucratic disposition. See Michel Foucault, Polurs and the Stud of Descourse, in THe Fotcallt EFFECT, supra note 1, at 53, 69-72.

30. The "sociology of critique" involves specitying the sucial, poltucal. and counomk processes that both enable and limit critucal practices That is, the soxiologist interested in critucism as at sox ial pratuce would analyze closely the socio-political condiuons of posstble cnicism Thus. the suxtulugy of cntuguc seeks to broaden the understanding of critical discourse by prowding a lens through which crith sl sehulars

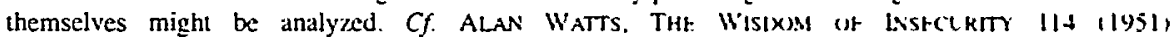
("Phílosophers ... often fall to recognise that their remarks about the uniserse apply stso to theriselice and their remarks."). My line of analysis clearly draws on worh done in the "sox tulugy of intellectuals"

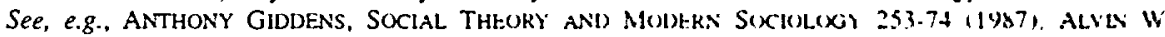

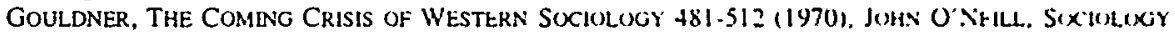
as a SKIN TRADE: ESSAYS TOWARDS a Rt:FleXINE SUClOLCGY (1972) 
between these pre-theoretical commitments and the theoretical orientation of CRT?

In Part III, I offer postmodern anthropology as an informative analogue. Analysis of anthropology's confrontation with postmodernism underscores the descriptive power of the notion of "pre-theoretical commitments." Anthropology's pre-theoretical commitment to the ethnographic method places discernible limits on the discipline's appropriation of postmodern critique. ${ }^{31}$ That is, the intellectual domain of anthropology is defined-as against other fields of inquiry and other forms of knowledge-by its commitment to the clarification of concepts such as "culture" and "difference" through ethnography. As such, the incoherence of ethnographic representation prefigures the incoherence of anthropology itself. The example of "postmodern anthropology" clearly demonstrates the proper limits of radical critique: The apex of critical discourse within any field of inquiry is a reflexive turn aimed at specifying the field's pre-theoretical commitments. ${ }^{32}$ Theoretical reflexivity-reflection upon the process of theorizing itself-generates what political scientist William Connolly calls "theoretical self-consciousness."

In Part IV, I apply the lessons of anthropology's encounter with postmodernism to CRT. I suggest that the critic's positionality-clarified by reflexive analysis-is a function of the relevant discourse's pre-theoretical commitments. Additionally, I argue that postmodern insights might inform a reflexive critique of CRT without renouncing the pre-theoretical commitments of CRT.

In Part V, I conclude with a reflection on Foucault's clarion call for "essays in refusal." I argue that understanding "criticism" as a socially organized practice with identifiable, foundational commitments counsels against embracing the Foucauldian notion of irreducibly oppositional critique.

31. For a discussion of the ethnographic method, sec infra Section III.A.

32. The understanding of reflexivity deployed in this Note is informed by Pierre Bourdieu's "reflexive sociology." See Pierre Bourdieu, The Logic of Practice (Richard Nice trans., Stanlord Univ. Press 1990) (1980); PIERRE BouRdieu, OUTLINE OF A THEORY OF PRACTICE (Richard Nice trans., Cambridgc Univ. Press 1977) (1972); Loic Wacqurant, Towards a Reflexive Sociology: A Workshop with Pierre Bourdieu, 7 SOC. THEORY 26 (1989). Bourdieu would carry the claim much farther than I would, however For Bourdieu, reflexive theorizing is not only the outer limit of critical practice, It is the only viable critical practice. See Pierke Bourdieu, Distinction: A Social. Critique of the judgement of Taste 12 (Richard Nice trans., Harvard Univ. Press 1984) (1979) ("There is no way out of the game of culture; and one's only chance of objectifying the true nature of the game is to objectify as fully as possible the very operations which one is obliged to use in order to achieve that objectification.").

33. Professor Connolly defines "theoretical self-consciousness" as:

[F]irst, an effor to clarify for self and others the basic presumptions and conceptual organization of the perspective brought to inquiry; second, an assessment of the extent to which the available evidence supports or contravenes the perspective; third, a lull statement of the normative impon of the theory; and, finally, an assessment of the extent to which avalable evidence and other explicst considerations justify acting in support of those normative conclusions.

William E. Connolly, Theoretical Self-Consciousness, in SOClal STRUCTURE ANI) POLITICAL THHokY 55, 57-58 (William E. Connolly \& Glen Gordon eds., 1974). 


\section{The POlitics of Reconstruction: The Perils of POSTMOder.NISM AND THE PRE-THEORETICAL COMMITMENTS OF CRITICAL RACE THEORY}

CRT is often characterized as "postmodern," is "antifoundational," "34 or "nihilistic." Given the controversy surrounding postmodernism in the legal academy, ${ }^{37}$ these characterizations (regrettably) inform much of the debate on the merits of CRT. ${ }^{38}$ Additionally, the genealogical relationship between CRT and Critical Legal Studies (CLS) gives rise to a deep tension in CRT that complicates the relationship between CRT and postmodernism. ${ }^{37}$ As a radical discourse utilizing CLS methodology, CRT challenges and rejects much of traditional liberal antidiscrimination law scholarship. "Toward this end, CRT is committed to revealing the ways in which the very concepts of "Equality," "Justice," and "Truth" are racialized in U.S. law." As a reformist discourse rejecting CLS's overly abstract analysis of rights, CRT is committed to the progressive realization of traditional, liberal notions of equality and justuce for minorities. ${ }^{42}$ CRT confronts the "specter of postmodernism" with this conflicted perspective.

34. E.g., MNDA, supra note 10 , di 182

35. E.g., Feldman, supra note 6. at 1102-04. Morauct/, supra nele 14 . at 434 is

36. E.g., Rosen, supra note 14. at 29

37. See supra notes 6-18 and accompanying text Given the controserss, this unstished nummalism

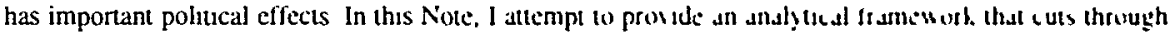
such nominalism.

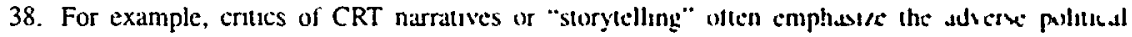
consequences of such perspectuvalism See. e g. Kathryn Abrams, Hearmg the ("ull of Siortes. 79 C \& L

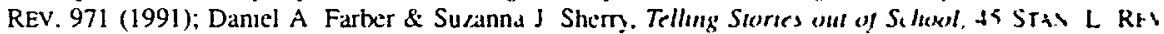
807 (1993).

39. CRT clearly has a complex relationshup tu CLS CLS emphasugts the ways m whe h law constructs and is constructed by pnvileged knowledge clams CRT. embraling ths Itameworb, in part, cmphastas

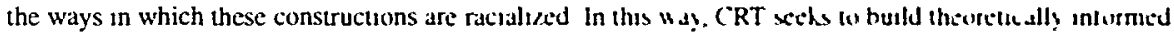
race consciousness in legal thought See Harlon Dalton. The Clouded Prism .Mumurn (rimique of the Critical Legal Studies Molement, $22 \mathrm{HaRv}$ C R.CL L. RH 435119871, Man Malsuda. Lasking bo thr Bottom: Critical Legal Studies and Reparattons, 22 HARs C R C L L RHS $323119 \mathrm{~s} 7$,

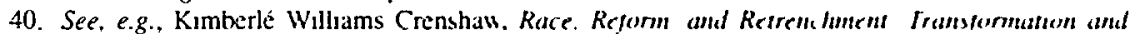
Legitumation in Antulscrimmation Lam. 101 HARV L RFV 1331 (198S)

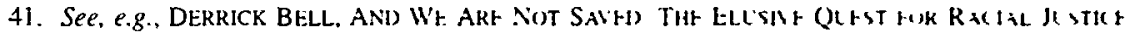
(1987); Derrick A. Bell, Jr, Brown v Bodrd of Education and the Interess (onserpente lulcrnma, Y3 HARv. L. Rev. 518 (1980); Delgado, supra nute 23. al 6-8. Ruchard Delgado 8 dean Stelanu, Wh, lo,

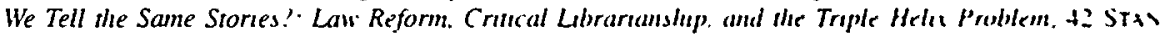
L. REV. 207 (1989): Richard Delgado, Derrich Bell and the Ideologs of Rethell Retonn Will Wre Eixe Be Saved?. 97 YALE L.J. 923 (1988) (book revew)

42. Professor Crenshaw makes this point forcelully

Critics also disregard the transtormatuve potential that hberalism offers Althughh hiberal legal ideology may indeed function to mystily. It remalns fecepunc to som: aspliatuons that at: central to Black demands. and may also perform an mpunant lunctuon in combating the expertence of being excluded and oppressed This recepusaly 10 Blath aspustiuns is cructal given the hostile social world that racism creates The most toubling apert of th: Critical program, therefore, is that "trashing" nghts consciousness mus hate the unntended conveyuence of disempowering the racially oppressed whlle lesung whice supremsal baskdly untuuthod Crenshaw, supra note 40 , at $1357-58$ 
In this part, I document the confrontation between CRT and postmodernism. Rather than canvass the disparate treatment CRT scholars give to various features of postmodern thought, I closely analyze one compelling account of the relationship between CRT and postmodernism: that of Angela Harris in The Jurisprudence of Reconstruction. ${ }^{43}$ The confrontation between CRT and postmodernism clarifies CRT's decidedly modernist pre-theoretical commitments to Truth, Equality, and Justice. That is, I claim that CRT could and should embrace postmodern thought only insofar as postmodernism furthers CRT's modernist pre-theoretical commitments. I am not concerned with the propriety of postmodernism as such; rather, I argue that the methods used to evaluate postmodernism are predetermined by CRT's discursive configuration.

Given the nature of my argument, the views of most scholars miss the mark. $^{44}$ Professor Harris's work, in contrast, offers a persuasive counterargument: CRT is, according to Harris, both a modernist and postmodernist discourse. A close reading of Harris's argument, however, reveals the ways in which her own account is shaped by CRT's modernist pretheoretical commitments. Even in defending the notion of a postmodern CRT, Harris appeals to identifiable, modernist criteria. In short, this analysis provides strong evidence of CRT's pre-theoretical commitments as well as the ways in which these commitments frame CRT's encounter with postmodernism.

Harris's article deftly maneuvers through the fundamental theoretical and political challenges facing $\mathrm{CRT} .{ }^{45}$ In doing so, it provides perhaps the most sophisticated reflection on CRT's confrontation with postmodernism. ${ }^{46}$ To engage The Jurisprudence of Reconstruction is to address the very heart-the conceptual center-of CRT. Indeed, Harris's project is foundational for CRT in at least two respects. First, the piece is metatheoretical in the sense that Harris seeks to understand CRT as a unified project. Harris seeks to elaborate a common foundation for $\mathrm{CRT}{ }^{47}$ Second, Harris addresses what, in my view,

43. Harris, supra note 22.

44. CRT scholars can be divided into two camps on the postmodernism issue. See supra notes 16-18 and accompanying text. One camp endorses postmodernism as an emancipatory practice that holds the promise of transforming stale liberal legal discourse into a meaningful conversation about freedom and equality. See supra note 16 and accompanying text. The other camp of CRT scholars is skeptical of postmodernism's emancipatory potential. See supra notes 17-18 and accompanying text.

45. The point worth underscoring here is that the challenges facing CRT within the academy are political as well as intellectual. See, e.g., Kimberlé Williams Crenshaw, Foreword: Toward a RaceConscious Pedagogy in Legal Education, 11 NAT'L BLACK L.J. I (1989); Richard Delgado, The Imperial Scholar: Reflections on a Review of Civil Rights Literature, 132 U. PA. L. REV. 561 (1984); Richard Delgado, The Imperial Scholar Revisited: How To Marginalize Outsider Writing. Ten Years Later, 140 U. PA. L. REV. 1349 (1992).

46. Other scholars have attempted to insulate CRT from the deconstructive excesses of postmodernism. See, e.g., Anthony E. Cook, The Spiritual Movement Towards Justice, 1992 U. ILL. L. REV. 1007 (urging a spiritual, Christian perspective, grounded in the philosophy of Martin Luther King, Jr., as a way for CRT to avoid postmodernism's threat of "nihilism").

47. Harris acknowledges this metatheoretical component of her project even as she disavows it: "A beginning word of caution: essays like this one inevitably indulge in the anthropomorphic fallacy, creating 
constitutes the central problem for the scholar-activist: "[W] hat in the end is the point of critique?"48

What is at stake in Harris's article is nothing short of the proper role for progressive scholars in the struggle for the liberation of historically (perpetually) oppressed groups. Toward this end, Harris calls for a "dual commitment" in CRT to both modernist and postmodernist narratives: "The seeming choice between modernism and postmodernism is an impossible one. The task is to live in the tension itself: to continually rebuild modernism in light of postmodernist critique."49

I disagree. Indeed, a close analysis of Harris's "dual commitment" model reveals the decidedly modernist pre-theoretical commitments of CRT as well as the ways in which these commitments structure even arguments advocaung a postmodern orientation for CRT. Harris frames this ostensibly productive tension as an ontological discontinuity between modermsm and postmodernism: ${ }^{50}$ "Modernism does not pretend that truth is easy 10 see, but it does insist that there is some truth, some authentic expenence and knowledge. In response, postmodernism doubts the notion of authenticity altogether, even the authenticity of the self."

In its modernist moments, CRT is deeply commitled to a viston of liberation in the sense that it aims not to topple the Enlightenment, but to make the Enlightenment's promises real. $" 2$ Conversely, in its postmodernist moments, CRT is profoundly skeptical of the conceptual, ethical, and political foundations of the Enlightenment, including "Truth," "Justice," and "Reason": "Even ideas like 'truth' and 'justice' themselves are open to interrogations that reveal their complicity with power." "The dual commitment is made not only to "antiracist" critique ${ }^{54}$ but also "to critucism itself." How might CRT inhabit this dialectic between the "romantic excesses of modernist fanth" and the "deconstructive excesses"s7 of postmodernist critique? What are the

a unified thinking and speaking subject where none exists Like all reductuons, then, this one will to misleading; and ... I invite the critique and subversion of my oun generali/altions "Harns, suprat note 22. at 744-45 (emphasis added)

48. Id. at 744 .

49. Id. at 744 .

50. For an argument that modemism and postmodernism are inconimensur sble "cosnutue modes," xec Pierre Schlag, Missing Preces: A Cogmme Approach to Law. 67 ThA L RFV 1195 (19b9, Mlany schuldrs emphasize the discontinuties between modernism and postmodernusm See e $g$. MICHiL Fotctilt. LANGUAge, COUNTER-MENoRY, PRACTICE 120 (Donald Buuchard \& Shery Simon trans, Comell Liny Press 1977) (1977); ANDREAS HUYSSEN, AFTER THE GREAT DNIIl) 1-64 (1\%93)

51. Harris, supra note 22, at 758 (emphasis added)

52. Modernist critucal practice emphasizes the ways in which Enhghtenment desls arte worthwhlc.

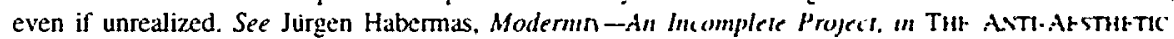
ESSAYS ON POSTMODERN CULTURE I (Hal Foster ed . 1983)

53. Harris, supra note 22, d 743

54. Id. at 751 .

55. Id. at 760 .

56. Id. at 767.

57. Id. at 741 . 
implications-political and theoretical - of such a positioning? My claims are forwarded in the spirit of questions that, in my view, should be foregrounded by CRT as it negotiates this contradiction that defines what it means to be a "radical scholar."

Should (or could) CRT aspire to avoid privileging the modernist over the postmodernist narrative? Even as Harris spells out postmodernist critiques of the Enlightenment, she seems to betray the methodological protocol that enables such radical critique in the first place. The issue I want to highlight here concerns the impulse to think, to write, and to critique. ${ }^{58}$ Where might CRT ground its raison d'être given Harris's account? That is, I want to interrogate the conditions of possibility for the proposition that "postmodernist narratives are productive for CRT." My contention is that CRT should-perhaps must-always evaluate this proposition by modernist standards of judgment. ${ }^{59}$ Indeed, Harris's account itself is driven by the belief that postmodernist narratives can productively contribute to the liberation of oppressed peoples.

Postmodernism assists CRT, according to Harris, by revealing the ways in which race is "always already" 60 inscribed in the most innocent and neutralseeming concepts. ${ }^{61}$ This revelation prompts Harris to call for an "aspiration toward disenchantment," ${ }^{\prime 62}$ by which she means

a mood that is always conscious of the limits of rational reason and the ways in which intellectual and legal formulations will always fall shcrt of their intended aims. Disenchantment implies a certain distance from the struggle to further social change through creative, more complex, and sophisticated social theory-even as we are wholly committed to it. ${ }^{63}$

Harris does not advocate "disenchantment" merely for the sake of complexity or creativity alone. Complexity and creativity open doors and reveal pathways to "liberation" that otherwise remain hidden or obscured ${ }^{64}$ For example, Harris brilliantly explicates the ways in which CRT narratives cannot be

58. See infra Section IV.C.

59. My very theoretical preoccupation with evaluation could be criticized as an impulse grounded in modernist faith. See Christopher NoRRIs, THE TRUTH ABout PostmodernisM 299-304 (1993).

60. The phrase was coined by French philosopher Jacques Derrida. For an extended discussion of the genesis and elaboration of the concept, see DIANA Fuss, ESSENTIALLY SPEAKING 15-21 (1989). 41.

61. This claim has been a central insight of the CRT movement. See, e.g., sources cited supra notc

62. Harris, supra note 22 , at 767.

63. Id.

64. "Liberation" is placed in quotation marks to acknowledge another side of the postmodern incjuiry centering on redefining what might constitute liberation. Harris highlights the liberation (modernist)/empowerment (postmodernist) dichotomy. See id. at 752-53. This formulation, however, must confront the question I pose here. That is, how might we determine whether a reconceptualization of "liberation" is productive? The standards used should always take as their point of departure the modernist faith that one can move from "understanding to action." Id. at 753. 
judged solely by rationalist standards. "Evaluations made withın whatever alternative framework one might employ, however, would turn on the degree to which the reconceptualization "works." This notion of "works" always already invokes a range of (best-left-unproblematized) concepts, formulations, and values. ${ }^{\text {to }}$

Postmodernist theoretical operations are made possible through bracketung the "truth claims" of modernism-subversion through suspension. This bracketing, in part, involves historicizing, contextualizing, and relattvizing the "truth claims" that ground modernism. Harris is right to point out the usefulness of such operations for CRT given the degree to which concepts such as "Justice" have worked to the disfavor of "mnnorities." Clearly, however, there is a danger here. Radical projects of auto-effacement threaten to paralyze CRT. ${ }^{67}$ An analytic distinction must be drawn between the Enlightenment project as lived experience and the Enlightenment project as loosely constructed, guiding ideals. ${ }^{\text {ox }}$ The commitment to Enlightenment ideals impels CRT's rejection of traditional liberal legal thought. Indeed, as my reading of Harris demonstrates, CRT's pre-theoretical commuments provide the criteria by which Critical Race Theorists would evaluate the utulity of postmodern critique.

In this part. I have suggested that the very ways in which CRT assumes an oppositional stance to traditional civil rights scholarship delimit $C R T$. This analysis suggests that CRT qua CRT involves certain pre-theoretical commitments; namely, CRT is committed to some conception of Truth, Equality, and Justice. The question regarding the relationship between CRT and postmodernism is properly specified as: What is the relationship between these pre-theoretical commitments and the theoretical orientation of CRT?

65. See id. at 745-54. of Richard Delgado. On Tellung Stories in Sthexl A Kephls to Farber and Shern; 46 VAND. L. REV 665.676 (1993) (argung that CRT should be sllowed a degree of turther experimentation before it is brought to judgment as a scholarly movement)

66. Among these is "fdath" in some ided of "jusice " What is CRT qua "illical" "ratce" "theon" without some sense of justice contmuoush inlorming its theoreucal operatuons,

67. For examples of what 1 consider to be "radical projects of sulu-ettatement," ser Jtex

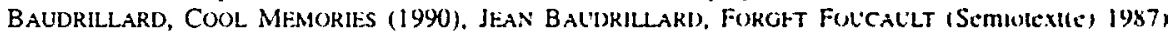
(1977); PAUL DE MAN. BLINDNESS AND INSIGHT (1971). and LrotakD), supra nule o These prujects ase "auto-effacing" in the sense that the duthors sell-conscrously adiance clams that undermine or invaludate the conceptual foundations upon which those very clans are bult, that is. the arguments die purposetully self-defeating. My claim is not that such projects are not useful, rather. $m$ ) clatm concerns the ways in

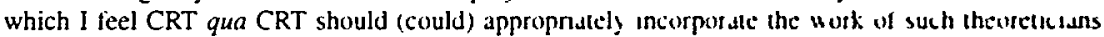

68. That is, criticism of modernity might be properly undersiond as well-grounded complatits that modernity--in practice-has not sufficiently realied its noble, if abstratt, aspiralions In the context of $L$ ' 5 law, CRT might be best understood as a challenge (o) legal hberalism to lise up to tis uwn standards See Frank I. Michelman, Foreword" "Racialism" and Reason. 95 MicH L RH 723 (1\%)7) I stguing that liberalism can be reconciled with CRT concepts if hiberalism is characternzed as a set of aspirations and not as a set of existung norms) 


\section{LESSONS OF THE REFLEXIVE TURN IN POSTMOdERN ANTHROPOLOGY}

CRT is not, of course, the only discipline to encounter the prospects and problems of postmodernism. Postmodernism has challenged the conceptual integrity of many scholarly discourses, including economics, ${ }^{69}$ history, ${ }^{70}$ literature, ${ }^{71}$ and politics. ${ }^{72}$ I claim that such encounters are always structured by the pre-theoretical commitments of the discipline in question. ${ }^{73}$ The detailed exposition of examples should clarify this rather abstract claim. Indeed, studying the selective appropriation of postmodernism in other disciplines would improve the understanding of postmodernism's place in the legal academy. Furthermore, an analysis of the ways in which pre-theoretical commitments inform radical theorizing in other disciplines clarifies the concept of "pre-theoretical commitments" itself. In this part, I outline the contours of the confrontation between anthropology and postmodernism. ${ }^{74}$ The radical skepticism of postmodernity-including the assault on realist, neutral modes of representation-threatens to render anthropological discourse incoherent. Drawing on the central proposition of this Note, I claim that anthropology's pre-theoretical commitment to the ethnographic method (broadly conceived) places effective limits on the ways in which postmodernism influences anthropological thinking.

Anthropology's confrontation with postmodernism demonstrates the ways in which the capacity of any discipline to reflect on its own foundations is limited. The in-depth case study of anthropological practice suggests that the project of "reflexivity"- - evaluation of a practice's theoretical orientation in light of its pre-theoretical commitments-is the height of critical discourse within any disciplinary domain. ${ }^{75}$ That is, the example of anthropology helps amend and answer the "postmodern question": How far can scholars go in

69. See, e.g., JeAN BaUdrILlard, THE MiRror of Production (Mark Poster trans., Telos Press 1981) (1977). 1987).

71. See, e.g., JACQUES DERRIDA, WRITING AND DIFFERENCE (Alan Bass trans., University of Chicago Press 1978) (1967)

72. See, e.g., POSTMODERNISM AND POLITICS (Jonathan Arac ed., 1990); RICHARD RoRTY, Postmodern Bourgeois Liberalism, in OBJECTIVITY, RELATIVISM, AND TRUTH 3 (1991).

73. Although I will not defend this thesis explicitly, my analysis is generally applicable to any theoretical discourse.

74. My discussion of anthropology concerns only socio-cultural anthropology. See generally CAKOL R. EMBER \& MELVIN EMBER, ANTHROPOLOGY 8-11 (6th ed. 1990) (describing distinctions between the subfields of anthropology). The emergence of socio-cultural anthropology as a discipline is welldocumented. See generally MARVIN HARRIS, THE RISE OF ANTHROPOLOGICAL THEORY (1968) (providing a materialist, evolutionary account of the history of social anthropology); GEORGE W. STOCKING, JR., VICTORIAN ANTHROPOLOGY (1987) (documenting the social and intellectual antecedents to contemporary social anthropology).

75. See supra note 32 and accompanying text; see also BARRY SANDYwELL, REFLEXIVITY AND THE CRISIS OF WESTERN REASON 376-98 (1996) (analyzing the relationship between what Sandywell calls "transactional reflexivity"-prominent in sociology-and philosophical reflexivity). 
questioning and subverting the theoretical underpinnings of any discipline's truth claims? The example outlined in this par suggests a deceptively simple amendment to the query: How far can anthropologists as anthropologists go in questioning anthropology's truth claims? Anthropology does provide conceptual resources for interrogating the discipline's knowledge claims. The question implies its answer: Anthropologists can go no further than a "reflexive turn"-anthropological reflection on the conditions of possibility for anthropological truth claims. ${ }^{76}$

\section{A. Postmodernism in Anthropology:: In Search of Post-Representational Ethnography'}

Ethnography is the predominant mode of representation employed by anthropologists." According to John Van Maanen, ethnography "rests on the peculiar practice of representing the social reality of others through the analysis of one's own experience in the world of these others."78 Viewed as a neutral vessel through which anthropological data are merely relayed, ethnography largely evaded both sustained criticism and significant revision for most of the twentieth century. ${ }^{79}$ Uncritical acceptance of representational schemes, however, became increasingly untenable with the rise of postmodernism. ${ }^{\text {st) }}$

76. Anthropological theonsts clearly understand "rellexivity" is a shicld aganst the excexses of postmodernism. See Lorraine Nencel \& Peter Pels. Crnique and the Deconstruction of Anthropological

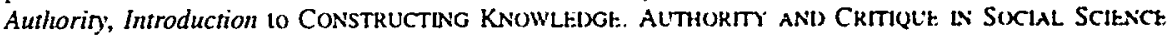
1, 2 (Lomaine Nencel \& Peter Pels eds, 1991) [hereinafter Consthucting KNowletxet] (arguing that "present so-called 'postmodem" attempts to reformulate the professional task of the anthropologist necessitate a restatement of the reflexive cntuque of anthropology")

77. By ethnography, I mean the written representation of a culture, or select leatures of a culture Two clarifications of this definition are in order. First, ethnography is distunct from licldwork (though heldwurk often provides the basis for echnographic wning) See JOHN VAN MAaNieN, TaLtS (ot THE FirLi) 4 (1988) ("Ethnography is the result of ficldwork, but it is the written repon that must represent the culture, not the fieldwork itself. Ethnography, as a written product, then, has a degree of independence thuw the culture is portrayed) from the fieldwork on which it is based (how culture is known) ") Second. ethnography reasons from the particular to the general That is. anthropological knowledge is profluced through the ethnographic representation of social life within panticular groups See Das SpkkBk. ON ANTHROPOLOGICAL KNOWLEDGE 95 n.3 (1982) ("."Elhnography" is generally used in a resinctuve sense it refers exclusively to the study of socio-cultural phenomena wilun a specific human group ") For a sound and highly readable introduction to the chnographic method. see VaN MAANEs, supra

78. VAN MAANEN, supra note 77, al $1 x$.

79. See JaMes Clifford, The PredicaMent of CULturk 21.53 (1988) (documenting and lamentang unchallenged "ethnographtc authonty" in anthropological discourse). George W Siocking. Jr. Histon of Anthropology: WhencenWhither, in OBSERVERS OBSERVED 1, 3-11 (George WV Stocking. Jr cd. 1983) (providing a brief history of the unreflectuve acceptance of the ethnographic method in anthropology)

80. As Clifford Geertz writes:

The problem of relating [anthropology] to the grand march of the social sciences was mude all the more severe by the fact that the philosophical disquictudes that had been gathering within those sciences during the previous two decades grew so powerful in the seventies and eaghties as to disarrange their sense of what 11 was they were all dbout The murat and epistemological vertigo that struck the culture generally in the post-structuralist. prost-modernist. post-humanist age, the age of turns and texts, of the evaporated subject and the constructed fact. struck the social sciences with particular force 
The postmodern challenge eventually produced widespread theoretical and methodological crisis in anthropology. ${ }^{81}$ This crisis, surely linked to the broader theoretical and representational crisis in the social sciences, ${ }^{82}$ involved a central methodological problem: how to produce objective concepts and objectively verifiable theories about social actors and social formations that are themselves always embedded in subjective meaning structures. ${ }^{83}$

In traditional ethnography, a knowing subject experiences an unmediated confrontation between self and object, the latter including both the "primitive" other and the constellation of "social facts." ${ }^{44}$ Through this confrontation, knowledge of other cultures is produced by the anthropologist. Thus the epistemological foundation of ethnographic texts rests upon the imputed ability to represent some aspect of the social field. This formula, however, fails to resolve the aforementioned methodological snare. Indeed, the problems associated with textualization as a means of representation are welldocumented in anthropological literature. ${ }^{85}$ Ultimately, the theoretical ground upon which empiricist ethnography rests is unstable in the postmodern world.

\section{B. The Reflexive Turn: Pushing the Limits of Critique}

Confronted by the postmodern challenge, anthropology must engage in critical reflection of its own theoretical underpinnings-that is, critical

Clifford Geertz, After the Fact 128 (1995). Postmodernism is often theorized as the source of epistemological and methodological "crisis." See CRISIS IN ANTHROPOLOGY (E. Adamson Hocbel ct al. eds., 1982); Vincent Crapanzano, The Postmodern Crisis: Discourse, Parody, Memory, in RekEadino Cultural ANTHROPOLOGY 87 (George E. Marcus ed., 1992).

81. See PAUl RABDOW, REFLECTIONS ON FIELDWORK IN MOROCCo (1977) (providing an insightful commentary on conducting anthropological fieldwork in the face of the representational crisis in the social sciences). Rabinow's own reflections were deeply influenced by postmodernity. Rabinow was wcll known as a disciple of Michel Foucault. See Herbert L. Dreyfus \& Paul Rabinow, Michel Foucault: BEYOND STRUCTURALISM AND HERMENEUTICS (2d ed. 1983).

82. See George E. Marcus \& Michael M.J. Fischer, ANThropology as Cultural Critique: AN EXPERIMENTAL MOMENT IN THE HUMAN SCIENCES 7-16 (1986).

83. See KirSten Hastrup, A PASSAGE to ANTHRopolocy 165 (1995) ("In so far as anthropology is concerned with human knowledge, this knowledge is positioned."). This problem is a central concern in the philosophy of the social sciences. See generally PETER WINCH, THE IDEA OF A SOCIAL SCIENCE 88 (1958) (arguing that sociological knowledge is possessed in only implicit and partial form).

84. See Chris Bongie, Exotic MEMORIEs 1-32 (1991) (describing "cxoticist discourse" in fin de siècle ethnography and literature); Deborah Gordon, The Politics of Ethnographic Authority: Race and Writing in the Ethnography of Margaret Mead and Zora Neale Hurston, in MODERNIST ANTHROPOLOOY 146 (Marc Manganaro ed., 1990). The concept of "social facts" was developed by the early sociologist Emile Durkheim. See Emile Durkheim, The Rules of Sociological MeThod 10 (1938). As Durkheim writes:

A social fact is to be recognized by the coercive power of external coercion which it exercises or is capable of exercising over individuals, and the presence of this power may be recognized in its turn either by the existence of some specific sanction or by the resistance offered against Id. every individual effort that tends to violate it.

85. See, e.g., CLIFFORD, supra note 79; WRITING Culture (James Clifford \& George E. Marcus cds., 1986); George E. Marcus \& Dick Cushman, Ethnographies as Texts, 11 ANN. REV. ANTHRopolooy 25 (1982); Paul Rabinow, Discourse and Power: On the Limits of Ethmographic Texts, 9/10 DiAlectical ANTHROPOLOGY 1 (1985-1986). 
anthropology requires "reflexivity." In this section, I outlune the essentual features of the "reflexive turn"-and its proper limits-in anthropology. Specifically, I highlight some recurrent themes in the anthropological critiques of anthropology. This brief survey illuminates three theoretically significant characteristics of anthropology's confrontation with postmodemısm. First, the postmodern challenge prompts theoretical introspection in anthropology. Second, anthropological reflection on any issue-including anthropological discourse itself-necessarily involves utilization of the disciplıne's conceptual resources. Third, these conceptual resources. without which anthropological inquiry is impossible, are properly understood as the pre-theoretical commitments of anthropology. In this way, "reflexive" theorizing-even when inspired by radical skepticism-proceeds from an identifiable, and indeed pretheoretical, starting point.

Consider. for example, Johannes Fabian's sweeping intique of anthropological theory, Time and the Other, ${ }^{\text {n }}$ which outlunes a program for "dismantling identifiable ideological devices and strategies which have been functioning to protect [anthropology] from radical epistemological critique." Fabian seeks to build a theoretical apparatus in which a truly reflexive anthropology would be possible. ${ }^{8 y}$ Such a "reflexive" anthropology clearly involves the recognition that anthropology as a cultural practice is itself socially, historically, and philosophically mediated. The "reflexive" tradition pushes the argument a bit further by using the positionality of anthropology as the conceptual centerpiece in the deconstructum and reconstruction of anthropological knowledge. ${ }^{90}$ The nature and constitution of anthropological knowledge as well as the practical and political effects of that knowledge-including both its content and its production-are thereby foregrounded as theoretical concerns. In this section, I explicate and evaluate the theoretical significance of this tradition, particularly in regard to some of the central conceptual problems plaguing anthropology, namely the problem

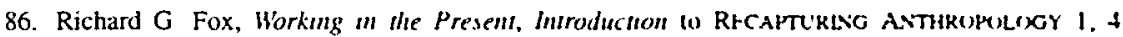
(Richard G. Fox ed., 1991) (describing the status quo in anthropology as an era of "irleflexwity. relativity, and the rejection of a privileged position for science or scholuship";

87. JOHANNES FABIAN, TMIE AND THF. OTH:R HOW ANTHKOPOLOGY MAKFS ITS OBIFCT (1983)

88. Id. at 152 .

89 The notion of reflexwity withn anthrepological discourse draus hessly on the puonering work of Bob Scholte. See RELNVENTING ANTHRopology (Dell H3 mes od, 1972) (culleclung essays rellectung on the path-breaking work of Scholte)

90. See Johannes Fabian, Dilemmas of Crutal Anthropology, in CoNsthl'ctwo KNowletxit. supra note 76, at 180 (describing the dual commitment to both deconsiructuon and reconstructuon), sec also MARTYN HAMMERSLEY, WHAT'S WRONG WTH ETHN(XGRAPHY' 43.56 (1992) (destribing ambivalence toward realism as the proper onentation for reunigorang anthropology Se generalls A ChaCK w THE MIRROR: REFLEXIVE PERSPECTIVES IN ANTHROPOL(DGY (Jdy Ruby co . 1962 ) (desinbing rellexivily d a deconstructive and reconstructuve perspectuve) 
of representation, ${ }^{91}$ subject-object distinctions, ${ }^{92}$ power, ${ }^{93}$ and the "other."94

Each of these issues is addressed in two respects by the reflexive turn. First, each can be studied cross-culturally; that is, one can engage in the anthropology of power, the anthropology of difference, or the anthropology of representation. Second, each can be analyzed in relation to the constitution and nature of anthropological knowledge itself. ${ }^{95}$ Simply put, these concepts and issues operate within anthropological discourse in constitutive ways-hence, "power" in anthropology, "difference" in anthropology, "representation" in anthropology. Both aspects of the "reflexive turn" in anthropology provide excellent examples of reflexivity's analytical contours. More specifically, anthropological reflexivity demonstrates some of the ways in which a scholarly discourse might productively appropriate postmodern critique without abandoning the discipline's pre-theoretical commitments.

\section{Representation: The Epistemological Status of Anthropology}

The nature of anthropological representation is a recurring and prominent theme in the reflexive tradition. ${ }^{96}$ The search for the "ethnographic real" has historically mirrored the search for an anthropology grounded in science." Every statement of "fact" already involves a selection procedure that precludes the use of such facts as a theoretically prior base.98 "Facts" are the irreducible building blocks of science; the claim that these facts are produced and mediated rather than discovered deals a staggering blow to empiricist methodology. ${ }^{99}$

91. See, e.g., WRITING CULTURE, supra note 85; Marilyn Strathern, Out of Context: The Persuasive Fictions of Anthropology, in MODERNIST ANTHROPOLOGY, supra note 84, at 80.

92. See Rabinow, supra note 85, at 3-9.

93. Issues of power are increasingly prominent in the social sciences. See 1 MICHEL, FoucAuLT, THE HISTORY OF SEXUALITY 93-95 (Robert Hurley trans., Vintage Books 1990) (1978) (providing a compelling and influential discourse-centered account of power). See generally BARRY HINDESs, Discourses of POWER: FROM HOBBES TO FOUCAULT (1996) (providing a useful summary of theories of power in social thought).

94. See generally EDWARD W. SAID, ORIENTALISM (1979) (providing the classic exposition of construction of the "other" through "orientalist discourse").

95. See, e.g., FABIAN, supra note 87 , at $143-65$ (describing power relations that structure and enable the anthropological project).

96. See, e.g., MARCuS \& Fischer, supra note 82, at 17-44; James Clifford, Partial Truths. Introduction to WRITING CULTURE, supra note 85, at 1, 1-26; Sherry Ontner, Theory in Anthropology Since the Sixties, 26 COMP. STUD. SOC'Y \& HIST. 126, 128-35 (1984).

97. See ClifFORD, supra note 79 , at $117-51$.

98. See, e.g., Stanley Fish, Normal Circumstances, Literal Language, Direct Speech Acts, the Ordinary, the Everyday, the Obvious, What Goes Without Saying, and Other Special Cases, in INTERPRETIVE SOCIAL SCIENCE 243, 248-63 (Paul Rabinow \& William M. Sullivan eds., 1979). Similar claims have been advanced with respect to the natural sciences. See generally BRUNO LATOUR \& STEVE WOOLGAR, LABORATORY LIFE: THE SOCIAL CONSTRUCTION OF SCIENTIFIC FACTS (1979) (arguing that the culture of laboratory settings, analyzed ethnographically, determines what comes to count as "factual").

99. See LATOUR \& WOOLGAR, supra note 98, passim. 
In this way, a fundamental insight of postmodernism has made its way into anthropological thought: Position mediates interpretation. The ethnographic observer therefore becomes an integral variable in the production of anthropological knowledge. ${ }^{100}$ Thus the reflexive tradition problematizes the oversimplified subject-object relationship that informs conventional ethnography. ${ }^{101}$ The ethnographer can no longer be viewed as a neutral observer operating simultaneously both inside the field of inquiry, as participant observer, and outside, as disinterested scientist. In the end, the confrontation of postmodernism and anthropology produces a rethinking of the status of anthropological knowledge. The position of the anthropologist in relation to a field of knowledge, the object of inquiry (which includes the ethnographer herself), and an overdetermined ethnographic genre are all constitutive parts of the ethnographic whole. ${ }^{102}$ On an analytic or descriptive level, the richness of this dynamic can never be fully exhausted.

Thus, postmodernism in anthropology has been appropriated as a means to reexamine and to refashion the ethnographic method. ${ }^{103}$ A double danger lurks in such an approach. On the one hand, these reconstructive endeavors seem arbitrary points of closure that betray the raison d'être of the reflexive tradition. ${ }^{104}$ On the other hand, eternal reflection on the production and form of anthropological knowledge threatens to reduce anthropology to "navel gazing." 105 The crucial question becomes: Is there a point at which

100. See Paul Rabinow, Representarrons dre Soctal Facts Modermun and Past-blodermun in Anthropology, in WRITEG CULTURE, supra note 85, it 234. 234-61

101. Marcus and Fischer propose the conception of "anthropology as cultural critique" in response to the deficiencies of the convenuonal ethnography Two styles of enuque inform the fomulation of d "cultural" critique: (1) an epistemological critique of analy ic reason that involves the "demysufication" of the relation between the content of beliefs, ideas, and the posittoning of their carriets, and (2) an institutional analysis that involves the analytic comparison of vartous sucisl instututions and cultural forms Cultural critique, then, has two related tasks. (1) to detect the vanous interests within discourse lormations (to expose ideology masked as "truth"); and (2) to forge a theoretteal apparatus sulficient to crituque the institutions of industrial society. See MARCUS \& Fischer, supra note 82. at 137.6-4

102. On the problematic notion of "ethnographic holism." see Roben J Thurnton. Tie Rhetoric of Ethnographic Holism, in REREAding Cultural ANTHRopoloor 15. 15.33 (George Marcus cd. 1992)

103. Such a reflexive approach provides the anthropologist with room to maneuver beiween unctitical realism and antifoundationalism. As Professor Hastrup wntes

Reflexive anthropology places itself between the poles of correspundence theury and constututure theory ... . The first claims to mirror reality, ontology and epistemulugy are une The secund disclaims this kind of realism and admits to consllutung reslity With \& truly retlexure anthropology we shall not have to make a choice, but shall be able to lise with the paradux of definitional realities.

HASTRUP, supra note 83 , at 50 .

104. Stephen Tyler is the most prominent proponent ot this view See Siephen A Tyler. Post-Hodem Etlmograply: From Document of the Occult to Occult Document. in Wkrtivg CLLTLkt. supra note 85. at 122.

105. Critics of reflexivnty wam of the solipsistic dangers inherent in sulu-critiugue These conterns are succinctly captured by the charge of "navei gazing." conjunng inuges of toundless, unproductuve sell. absorption. See, e.g., Bruno Latour, The Polincs of Explanahon An Aliernulue. "n Kvowltixt dNi) REFlEXIVITY: NEW FrontIERS IN THE SOCIOLOGY OF KNowlel)G 155. 155 (Steve Woolgar ed. 1988) As Latour writes,

Reflexiv[e] . . sociologists are sawing the branch upon which they sit Theif arguments in feeding back on themselves nullity their own tlums They are. in elfect. sell-cuntradictury. 
statements about anthropology become viable anthropological statements? Surely points of closure are inevitable and productive even if such points are properly understood as transient and unstable. ${ }^{106}$ The theoretical terrain, even when understood as always already problematized, must honor the pretheoretical commitments of anthropological discourse in order to retain any integrity as anthropological knowledge.

The constructive proposals offered by reflexive theorists, then, should not be read as dogmatic proclamations on "the right and only way to do anthropology"; rather these schemes represent necessarily incomplete reformulations-"experiments," according to George Marcus and Michael Fischer. ${ }^{107}$ To address these issues appropriately, a reflexive position is necessary - one in which the conceptual and representational tools are most appropriately fashioned through continual reflection on both the nature of the anthropological encounter with the "other" and the status of the "other" within that encounter.

\section{An Anthropology of Anthropology}

The recognition of anthropology as a culturally mediated activity situates anthropology, the cultural practice, clearly within the domain of anthropology, the academic discourse. This bifurcation of the anthropological realm rests uneasily in its tenuous construction. Indeed, the very notion of an anthropology of anthropology is wrought with conceptual difficulties. ${ }^{108} 1$ argue, however, that the anthropology of anthropology-reflexivity taken to the extreme-is the height of critical theoretical inquiry within anthropology. Pushing the inquiry further would require the use of other conceptual resources.

An anthropological inquiry into the nature of anthropology as a cultural phenomenon would necessarily involve demarcating the set of practices-material (methodological) and symbolic (epistemological)-that define the place of anthropology in a broader social field. If, however, the object of the inquiry is the very nature of anthropology, then there can be no stable, locatable anthropological subject engaging in such an inquiry. Thus anthropology answers the question "what is anthropology?" in necessarily partisan and partial ways. An anthropology of anthropology then presumes an understanding, or positioning, of anthropology both as a cultural practice and as an academic discourse. Yet this received understanding itself is an integral

or at least entangled in a sort of aporia similar to the famous 'all Cretans are liars,' an aponat

from which they cannot escape except by indefinite navel-gazing . . . .

Id.; see infra Section III.C.

106. See Tyler, supra note 104 , at 122-23.

107. MARCuS \& FisChER, supra note 82, at 40-44. The subtulle of this classic work reads: "An Experimental Moment in the Human Sciences."

108. These difficulties are, however, beyond the scope of this Note. 
aspect of the inquiry. How then is it possible to reflect on this pnor, unexamined frame within which an anthropology of anthropology becomes possible? How can one study anthropology anthropologically if the onentation of such studies is itself in question?

A reflexive turn in any discipline will invariably involve the son of conceptual opportunities and difficulties outlined in this section. The necessity and the impossibility of forging a radical break with the dominant episteme, to "think otherly," 109 present themselves at the edge of epistemological crisis - an edge at which "radical" critique faces the constant threat of theoretical reabsorption into conventional modes. ${ }^{110}$

\section{Understanding Ethnography as Pre-Theoretical Commument: \\ The Discursive Limits of Posmodern Antropology:}

Critics question the coherence and relevance of a postmodern anthropology. In many respects, such claims are persuasive. First, postmodem anthropology, by emphasizing anthropology's representational strategles (the "textual turn"111), shifts the analytic focus away from anthropology's traditional orientation, the study of cultural forms and processes. Second, postmodern challenges to ethnographic representation undermine the conceptual integrity of all claims about culture and difference. For these cntics, postmodern anthropology challenges the very notion of anthropology, not simply a particular conception of the anthropological project. Crutics of postmodern anthropology compel social scientists to ask: What is anthropology, in the end, if not the representation and analysis of vanous cultural formations? In this section, I analyze the structure of the debates in anthropology concerning the utility of postmodernism.

Nicole Polier and William Roseberry offer a critical review of the postmodern movement in anthropology, "12 focusing on two works: Writung Culture, edited by George Marcus and James Clifford," and Anthropology as Cultural Critique, written by George Marcus and Michael Fischer ${ }^{11:}$ The critique presented by Polier and Roseberry revolves around the clam that the postmodern preoccupation with genres of representation has "obstructed a serious consideration of the social, political, cultural, and individual contexts in which ethnographic knowledge is produced and consumed "

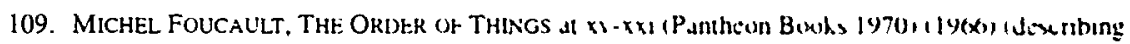
the difficulties and necessity of leaming to "think otherly",

110. See id.

111. See Clifiord, supra note 96. at 1-26

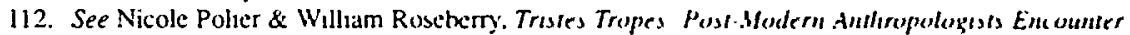
the Other and Discoser Themsehes. 18 ECON \& Suc'1 245 (1969)

113. WRITLNG CULTURE, supra nole 85

114. MARCUS \& Fischer, supra note 82

115. Polier \& Roseberry, supra note 112, at 246 
the claim is advanced that postmodernism, particularly "postmodern ethnography," does not and cannot produce an adequate account of culture and difference. ${ }^{116}$

For Polier and Roseberry, the postmodern turn in anthropology blurs the received distinction between fiction and ethnography. 117 "Postmodern" ethnography, then, ignores the fact that the context of ethnographic textual production is one of unequal power and knowledge and in so doing reproduces the privileged positioning of the anthropologist. ${ }^{118}$ The rejection of ethnographic realism by Marcus, Fischer, and Clifford does not, however, involve a rejection of "representation" as an enterprise. ${ }^{119}$ What is sought is a more authentic, theoretically informed representation. ${ }^{120}$ "Postmodern" ethnographers do not advance the argument that anthropology cannot function as an "interpretive community." 121 Indeed, "the events we see and the stories we are told constrain us" ${ }^{\prime 22}$ insofar as scholars see them and hear them (and textualize them) as anthropologists. Postmodern anthropology seeks to understand more fully the particular ways in which the "facts" constrain anthropologists through a better understanding of the process by which "facts" are represented in ethnographies. That is, postmodern anthropology provides a better understanding of the process through which the nature of the anthropological encounter is made available as anthropological knowledge-an understanding of how experience both becomes and mediates knowledge. ${ }^{123}$ The unique way in which this process occurs in and as anthropology necessarily involves textualization. ${ }^{124}$

For the postmodern theorists, ethnography is necessarily and irreducibly textual-that is, anthropology qua anthropology involves the practice of textualization. ${ }^{125}$ The inscription of the "other" into texts, whether it be

116. Id. at $248-49$.

117. See id. at 248.

118. Indeed, this hidden power relation, the "ideology of dialogic production," occurs within a context where "the ethnographer's privilege is precisely a discourse on the discourse." Il. at 252.

119. See MARCUS \& FISCHER, supra note 82, at 67. In fact, the experimentation with form and presentation of ethnographic texts is explicitly described as a "modernist" project: "If realist texts continue the convention of allowing the ethnographer to remain in unchallenged control of his narrative, modernist texts are constructed to highlight the eliciting discourse between ethnographer and subjects or to involve the reader in the work of analysis." Id.; see also Renato Rosaldo, From the Door of His Tent: The Fieldworker and the Inquisitor, in WRITING CULTURE, supra note 85 , at $77,88$.

120. See MARCUS \& FISCHER, supra note 82 , at $42-43$ ("We view the current experiments as adapting and bringing anthropology forcefully into line with its twentieth-century promises of authenticully representing cultural differences and using this knowledge as a critical probe into our own ways of life and thought.").

121. See, e.g., STANLEY FISH, IS ThERE A TEXT IN THIS Class? 1-17, 268-92 (1980) (describing the concept of an "interpretive community").

122. Polier \& Roseberry, supra note 112 , at 251.

123. See HASTRUP, supra note 83 , at 50 ("In anthropology . . reflexivity starts-not as a particular style of writing but as an inherent element in any empirical ethnography.").

124. See generally CLIFFORD GEERTZ, WORKS AND LIVES: THE ANTHROPOLOGIST AS AUTHOR (1988) (analyzing anthropology's strategies of textualization).

125. See, e.g., Rabinow, supra note 85 , at $1-5$. 
thought as a translation or a representation, ${ }^{120}$ lies at the heart of anthropology. Anthropologists are trained principally through the supervised reading of texts (and texts on other texts). Indeed, the notion of an increasingly inclusive ethnological theory relies upon the use of ethnographic texts as viable substitutes for fieldwork. Anthropology necessarily operates within a context of textualization with its commensurate social, political, cultural, and economic effects.

Given this pre-theoretical commitment, the anthropologist concerned with radicalizing theory must engage in a "systematic unlearning" of her privilege. ${ }^{127}$ That is, western intellectual production may in many ways be complicit with contemporary global power relations. Anthropology needs to articulate its political, historical, and theoretical conditions of existence that continue to reproduce the power relations between the West and its "others," and that give authority to certain descriptions or accounts while silencing others.

Polier and Roseberry's critique does underscore the appropriate limit of postmodern anthropology: Theorists cannot ignore the relations between representational forms and social practices-anthropology should not be reduced to "navel gazing." Given this limitation, reflexivity in anthropology should clarify the preconditions of anthropological knowledge with the furtherance of anthropological understanding in mind. ${ }^{128}$ These criticisms are illuminating in at least two respects. Such critiques demonstrate that anthropology occupies a bounded discursive domain organized around identifiable pre-theoretical commitments. In addition, the debates surrounding these criticisms reveal that postmodern anthropology-itself ensconced in anthropological discourse-shares the discipline's pre-theoretical commitments. Both the questions asked and the answers provided prove instructuve.

In short, the lessons of postmodern anthropology demonstrate the usefulness of the "pre-theoretical commitments" concept. Postmodernism confronts anthropology as a challenge to the foundational, pre-theoretical commitments of the discipline, prompting a reflexive turn. This introspectuve reflection on the discipline's pre-theoretical commitments clanfies the nature of these commitments, thereby enabling theoretically informed reconstruction. Deconstruction and reconstruction take place within this discursive domain, and this understanding of anthropology's confrontation with postmodernism

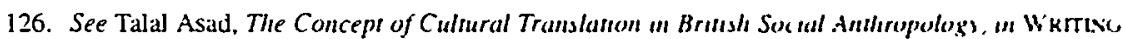
CULTURE, supra note 85, at 141, 160-64 (explasning the dillerence between collig̨ues of ethnogtaphic representation and ethnographic (ranslation)

127. Gyatri Chakravony Spivak, Can the Subaltern Speak'. In MakxisM +Nit tut INTrkpkttatuoy of Cultures 271, 295 (Cary Nelson \& Lawrence Grosstxig eds. 19901

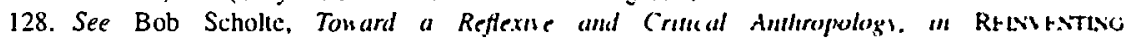
ANTHROPOLOGY 430, $451 \mathrm{n} .9$ (Dell Hymes ed 1969) ("Wic must also contront the pratical prublem ot formulating a concrete anthropological praxis The fatt that I cannes do so here stwuld not blind us to the obvious danger of substuluting a mere theory of praxis fon its atual reslizstion") 
underscores the importance of pre-theoretical commitments in structuring any such encounter.

\section{REFLEXIVITY AND THE DISCURSIVE LIMITS OF CRT}

Debates about the prospects or propriety of postmodern CRT should heed the lessons of other disciplines. Toward this end, this part draws two lessons from anthropology's encounter with postmodernism. First, pre-theoretical commitments delimit potential theoretical maneuvering; not even postmodernism's plasticity can outflank this discursive imperative. As discussed in Part III, postmodern anthropology clearly operates within welldefined discursive boundaries. Second, reflexive theorizing enables the postmodern anthropologist to experiment within the confines of these pretheoretical commitments. The critical point here is not that patterns of socially organized practice preclude conceptual and normative transformation. Rather, the point is that as long as the pre-theoretical commitments of any field retain some currency among its practitioners, the theoretical landscape will invariably conform to these discursive limits. ${ }^{129}$

The lessons learned from postmodern anthropology suggest that the effective limit of critical discourse resides in reflexive critique-understood as theoretical reevaluation in light of a more fully developed understanding of the discourse's pre-theoretical commitments. This part offers provisional reflections on ways in which CRT might utilize postmodernism both to elaborate its pretheoretical commitments and to reconstruct the theoretical framework of CRT. Specifically, I make three related claims. First, CRT should analyze the multidimensional positionality from which CRT speaks. Understanding CRT as an academic discourse with attendant benefits and constraints would inform the reflexive elaboration of CRT's pre-theoretical commitments. To elaborate this point, I analyze Patricia Williams's CRT critique of market ideology. Second, reflexive CRT should analyze race and racialization (as well as CRT itself) as discursive formations. Discourse analysis, I contend, provides a framework that complements reflexive theorizing by closely tracking the relationship between the ideal and the material. In Section IV.B, I outline some of the constitutive features of this framework. Third, reflexive CRT-to avoid devolving into "navel gazing"- must remain ever attentive to its pre-theoretical commitments. I suggest that an understanding of the impulses driving CRT would and should inform CRT's appropriation of postmodernism. In the end, "reflexive CRT" must involve both a "reflexive" CRT and a reflexive "CRT."

129. In addition, the nature of CRT's pre-theoretical commitments also helps illuminate the character of "pre-theoretical commitments." Consider an obvious surface distinction: Anthropology's pre-theoretical commitments are methodological, while CRT's commitments are political. In my account, however, the theoretical significance of CRT's political commitments is identical to anthropology's methodological commitments. 
A. Positioning the Critique: Understanding CRT as an Academuc Discourse

Reflexive critique involves understanding the situatedness of Critical Race Theorists in multiple intersecting spheres. An exhaustive list of these levels of analysis is beyond the scope of this project. By way of example, however, consider the market positioning of Critical Race Theorists This example proves useful since market positions intersect CRT at the two analyucally relevant levels: CRT theorizes markets and market ideology, and CRT IIself operates within a market. That is, CRT analyzes markets from a particular market position. In Spare Parts, Family Values, Old Children. Cheap, "so Patricia Williams analyzes the production and reproduction of race in market ideology. I hope to evaluate the degree to which Professor Williams's analysıs functions effectively as a critique of the "market" and market idcology. This section seeks to elaborate further the complex interconnections between race, racism, and the market by examining, in part, the conditions of possibulity for CRT critiques of the market. Such an exposition reveals ways in which CRT might operate reflexively within the discursive constrants of race, subordination, and liberation. This involves marking Professor Willians's positionality as an investigating, writing subject engaged in a project that cannot be located outside the dynamics of the market ideology A substanuve concern for the politics of the oppressed can mask a privileging of the intellectual which may, in turn, compound the difficulty of the project. CRT should involve a commitment to rendering visible the histoncal and institutional structures from which legal scholars, including Critucal Race Theorists themselves, speak.

CRT must theorize itself as a product of the civil rights tradttion, even as it seeks to elaborate alternative empowerment strategies. Critual Race Theorists speak from a highly assimilated position. My point is not grounded in class determinism. Rather I hope to underscore some of the ways in which the market-driven "self-negation" described by Williams" operates on the CRT project itself. Williams highlights two tactics used by racial minontıes faced with overwhelming assimilationist pressures: "success by dissembling,"132 which refers to the tactic of dissembling whiteness to achieve economic success; and "scatter the pigeons." "which refers to the tactic of shocking members of the privileged racial group by enactung feared or otherwise repudiated stereotypical behavior. Both tactics underscore some of the ways in which markets are racialized. Dissembling whiteness is theorized as a condition of possibility for success in our racialized market

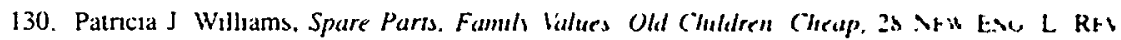
913 (1994).

131. Id. at 927.

132. Id. at 922 .

133. Id. 
Conversely, market pressures impel racial minorites to "scatter the pigeons" as a means of disavowing the hypocrisy that permeates dissembling.

The tension between the self-understandings informing these two coping strategies captures some of the "paradoxical logic" that informs the assimilationist tendencies of market ideology: The critical race theorist must comport with dominant conceptions of the "minority legal scholar" while continuously positioning herself in critical opposition to these conventional understandings. How does one inhabit such a space? Gayatri Chakravorty Spivak has remarked that "[p]ersistently to critique a structure that one cannot not (wish to) inhabit is the deconstructive stance."134 The conceptual impossibility of such a stance must be negotiated at every turn.

CRT must theorize the privileged position from which Critical Race Theorists speak. Law professors are conferred with material and symbolic privilege, which often places them in an odd relation to the objects of their inquiry: What law professors write and teach has political and other actual consequences for others that are different from the consequences, or lack of consequences, for the scholars themselves. ${ }^{135}$ Critical Race Theorists, in a sense, speak from a position of relative exile-exile from the harshest material realities of racism and capitalism. ${ }^{136}$

The work of law professors is inherently marked by a complex web of market relations; writing and teaching is after all a means of subsistence. My claim is not that Critical Race Theorists must avoid the commodification of liberatory thinking to preserve the conceptual integrity of their project; rather I am suggesting that the radical impossibility of such an avoidance must inform any critique of the market or market ideology. The claim, in fact, could be pushed further. Perhaps silence on this matter is wrought with political and conceptual pitfalls. Explicit recognition of the privileged position from which she speaks might inform projects like Professor Williams's article in a number of ways-some of which cut to the heart of the enterprise. First, assimilation might be a condition of possibility for effective anti-systemic critique. Second, the degree to which the very act of writing is complicit with the structures under critique must be understood. This involves an explicit recognition of the commodified status of the liberatory project as it is inscribed in legal scholarship even as CRT engages in the discursive disavowal of that status. As Williams demonstrates so forcefully, market ideology is most invidious when invisible; its very power in a sense is dependent on its transparency. An

134. Gayatri Chakravony Spivak, Constitutions and Culture Studies, in LEGAL STUDIts AS CULTURAL STUDiEs 155, 169 (Jerry Leonard ed., 1995).

135. Edward Said has made the same point with respect to anthropology. See Edward Said. Representing the Colonized: Anthropology's Interlocutors, 15 CRITICAL INQUIRY 205 (1989).

136. This problem confronts any scholar in the West interested in analyzing forms of oppression and domination. See id. at 207-12; see also Gayatri Chakravorty SpivaK, The Post-Colonial Critic. INTERVIEWS, STRATEgIES, Dialogues 75-94 (Sarah Harasym ed., 1990) (describing the multiple ambivalences of an "exiled" positionality). 
interrogation of the relation between race and the market must involve an examination of the peculiar institutional seat of Critical Race Theorists As a consequence, Critical Race Theorists could develop workable theones to understand more fully the nuanced relation of intellectuals to progressive or emancipatory movements.

\section{B. Understanding CRT as a Discursive Formatom: Developing a $C R T$ of $C R T$}

As the case of postmodern anthropology demonstrates, reflexive theonzing can devolve into "navel gazing." 137 In the attempt to develop a CRT of CRT, the pre-theoretical foundations that are isolated and elaborated through reflexive theorizing might prove illusory. That is, the very process that generates a rich understanding of CRT's pre-theoretical commumentsreflexive theorizing-could destabilize these foundations. ${ }^{13}$ The danger, as described by Pierre Bourdieu, is that reflexive theorizing ". becomes its own end [and] opens the door to a form of thinly-veiled nihilistıc relatıvism . . that stands as the polar opposite to a truly reflexive social science." "is CRT, as currently constituted, faces no such danger. Reflexive CRT-as an instance of CRT-must, and indeed would, always embody the pre-theoretical commitments of CRT discourse.

Discourse analysis would provide a framework for pushing the inquiry beyond potential conceptual brick walls. By discourse analysis, I mean studying the ways in which thinking and speaking shape and, in turn, are shaped by structures of power. ${ }^{1+0}$ Discourse analysis would emphasize the social and material basis of producing knowledge. ${ }^{141}$ Such an approach would create theoretical space within which one could both pursue reflexuve critique and understand the full progressive potential of CRT. Discourse analysis would allow CRT to analyze the ways in which systems of ideas acquire a materiality - that is, to understand how certain conceptions of race came to be dominant to the exclusion of other explanations ${ }^{1 * 2}$ Discourse

137. See supra note 105 and accompanying text

138. This seeming paradox partly explans the tdentucatuon belween tetlexwily and postmexlernty

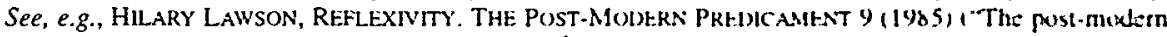
predicament is indeed one of crisis, a crisis of our truths, our values, wur must chenshed beliels A crists that owes to reflexivity its ongin, its necessity. and its force ")

139. Wacqurant, supra note 32, at 35 (quoting Pierre Bourdicu)

140. This understanding of discourse analysis draws hedsily on the work al foucdult See $\&$.

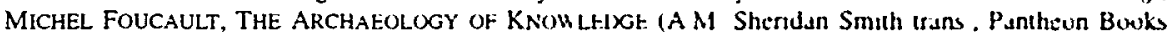
1972) (1969): Foucault, supra note 29. at 54-72

141. This approach postulates an analytic distuncion between concept anslysis and disciourse analy sis

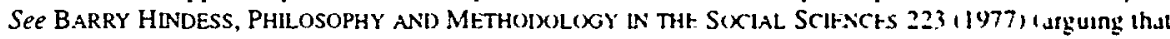
a "rigorous separation should be mantained lbetween] the loglical character of the urder of concepts of discourse [and] the process of production or generanon of discourse" (cmph.tsis dedded"

142. Foucault s concept of the critical operation "gencalogy" provides the bathdrop lies thes clatm Ser

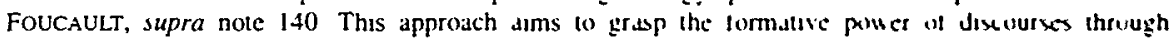


analysis emphasizes the processes that produce and constitute social subjects, identities, and their relations. ${ }^{143}$

Discourses have real effects. They are not just the way that social issues get talked and thought about; they structure the possible. ${ }^{144}$ As such, the discourse of CRT is intimately connected to a set of non-discursive institutional practices and systems of power. Other approaches risk underestimating the degree to which the discourse of CRT structures both the understanding of race as a social phenomenon and the identities of those about whom the discourse produces statements. The discourse of CRT should be understood as part of a system of statements about the relationship between race and the law that have become self-evident. An effective progressive politics requires an understanding of the stability and the imputed coherence and lucidity of the prevailing conceptions of race in the legal academy and beyond.

Discourse analysis would also allow CRT to define the limits of appropriation. That is, such an approach would enable CRT to describe which classes or groups have access to a particular discourse and the political effects produced by this differential access. This field of inquiry would help expose several relations: the relation between the author and the discourse employed; and the relations between classes, groups, or "races" as they struggle for control of the discourses of race and CRT. With these analytical elements in mind, CRT could better assess its role in the construction and reproduction of notions of race and justice by providing a richer exposition of prevailing power relations.

\section{Understanding the Impulse Driving CRT: Reflexivity as a Precursor to Reconstruction}

Reflexivity provides critical theorists with the analytical tools needed to understand the impulses driving critique. ${ }^{145}$ Interrogation of the impulses driving any critique reveals the vital distinction between method and rationale.

\footnotetext{
analyzing the ways in which discourses constitute "objects" or "classes of objects" available for study, is well as the ways in which discourses constitute these objects as subjects of statements that can themselves be judged as "true" or "false." Genealogy tries to get at the power that makes possible and legitimate certain kinds of questions and statements to the exclusion of others.

143. See DiANe MACDONELL, Theories of Discourse 101-18 (1986).

144. See FouCAULT, supra note 140, at 8-31; see also MACDONELL, supra note 143, at 89-94.

145. See Dorothy E. SMITH, The Conceptual Practices of Power: A Feminist Sociolooy or KNOWLEDGE 4 (1990). Professor Smith, in defining "reflexive inquiry," provides a persuasive account of reflexivity's theoretical purchase: "IW]hat we make here an object of investigation is what we ourselves are immersed in. The ideological practices explicated here are our own. Explicating such practices enables us to become aware of how, in deploying them, we participate in the relations of ruling." Id.
} 
If, as Angela Harris suggests, the impulse grounding modernism is faith $^{146}$ and the impulse grounding postmodernism is skepticism, ${ }^{167}$ then modernism should always serve as the rationale driving CRT-standing outside of and prior to the methodological choice between postmodem narrative, modern narrative, and Harris's "dual commitment" model. ${ }^{145}$ Given this formulation, Harris's dialectical account seems misleading. Modernism and postmodernism should not be theorized as the polar regions of a "productive tension," in that postmodernism should not serve as a counterweight to modernism in CRT. Rather, postmodernism should be theorized as an approach or a route to a modernist promised land. Authentic postmodern moments are only possible in CRT at the very moments in which CRT effaces the conditions of its own possibility. At those moments a new project emerges-an unknown project that Critical Race Theorists would only pursue given their "modernist faith" in what awaits them on the other side.

\section{CONCLUSION}

This Note suggests that the prevailing accounts of CRT's relationship to postmodernism do not explain the extant discursive limitations of CRT That is, CRT—as a socially organized practice-could and should only appropriate postmodern theory in ways that are consistent with CRT's pre-theoretical commitments. Three related propositions are suggested by this analysis. First, CRT-even in its most deconstructive moments-embodies identifiable pretheoretical commitments. Second, these pre-theoretical commitments provide firm foundations that structure CRT as a theoretical and practical discourse Third, the source of these foundations is social.

Angela Harris's appealing account of postmodernism in CRT seems descriptively inadequate given the analysis developed in this Note. Of course, Professor Harris is in some sense well aware of the problems I point to here. The formulations in her piece are made in the way of suggestions-the clearing of theoretical space. She invites the "critique and subversion" of her own provisional generalizations. ${ }^{149} \mathrm{My}$ ' position in this Note, however, is informed by the belief that the invitation to critique and to subvert must at some point be withdrawn. The moment of this withdrawal-the point at which the critic will have worn out her welcome-would in many important respects be determined by unmistakably modernist political calculations. Decisive questions would and should be asked. Is the critique paralytic? Is the critique productive? Aversion to the paralytic and aspiration to the productive constitute part of the modernist terrain that CRT should properly call its home.

146. See Harris, supra note 22, dt 753

147. See id. at 748.

148. See id. at 745; supra notes $49-51$ and accompanying text

149. Harris, supra note 22. di 744 
CRT is simply not in the business of formulating "essays in refusal." Neither is anthropology. Just as anthropology is necessarily committed to the conceptual coherence of ethnography, CRT is committed to some notion of Truth, Justice, and Liberation. For the critical scholar, the idea of "essays in refusal" is alluring. Indeed, practitioners of any critical discourse do not likely consider themselves as engaging in "ministerial cabinet talk." This Note suggests that for many this orientation, properly conceived, is both productive and-given the normative commitments of these critical discourses-ultimately indispensable. 